\title{
The Final Splendour of an Aged Empire: Chinese Thought on International Law in the early Twentieth Century
}

\section{Ping $\mathrm{Yi}^{*}$}

Until the late nineteenth century, the history of international law was remarkably Eurocentric. In the early twentieth century, however, a number of Chinese intellectuals examined and demonstrated existence of international law through the Spring and Autumn and Warring States Period in China. They used international law as a symbol of civilisation to express a gesture of resistance toward the Western imperial oppression and cultural invasion. In this way, Chinese intellectuals hoped to maintain, publicise, or even resurrect China's rich cultural tradition in a global order governed by the West. Their endeavour represented an important variable in the European imperialist expansion process and constituted political interaction with western ideas to create a truly universal discourse. Unfortunately, most of their efforts have almost been forgotten. What the readers could perceive from these faded writings are not only academic assertions, but also the final splendour of an aged empire.

\section{Keywords}

Ancient Chinese international law, Civilisation, Chinese intellectuals, Spring and Autumn and Warring States Period, Wanguo Gongfa

* Associate Professor of International Law at Peking University (PKU), China. LL.B./LL.M.(PKU), LL.M.\& Ph.D.(U. Tokyo). ORCID: http://orcid.org/0000-0001-5534-962X. The author may be contacted at: yiping@pku.edu.cn / Address: Room 203, Law School Building, Peking University, 5 Yiheyuan Road, Haidian District, Beijing, China 100871. 


\section{Introduction}

Basic ideas and principles of modern international law originated in Europe. This European international law was introduced widely through colonial expansion under imperialism to Asia, Africa and Latin America. ${ }^{1}$ With their eventual 'acceptance," European international law finally became a universally applicable global norm. ${ }^{3}$ Nineteenth century was indeed the time of "a widening of European international law."

In China, however, this process of 'widening' was faced with serious obstacles due to her long history and cultural traditions. Deep roots in the "Hua-Yi 華夷(Sinocentrism) distinction" established complex attitudes toward the alien (Western) world order. In the beginning, Chinese intellectuals tried to understand this unfamiliar European idea in the traditional sense including the Confucian conceptual framework. They tried to connect Chinese traditions to Western theories. In the end, however, European international law failed to supplant conventional Chinese legal culture. Instead, the Chinese spirit was embedded in the understanding of European international law; this combination allowed for the dissemination of international law in China. ${ }^{5}$

In the early twentieth century, ideological and cultural collision between (East) Asia and the West were fast escalating to a peak. Many intellectuals at the time

1 The "non-European regions" refer to countries and regions other than those in Europe and the US before the twentieth century. In 1836, the American international law scholar Henry Wheaton, for the first time, included the United States and European countries in the "civilized and Christian" world of international law. See H. WhEAton, ElEmENTS of International: With a SKetch of the history of the SCIENCE, vol. I, 11 (London: b. Fellowes, 1836). The notion of 'the West,' as appears below, also mainly refers to Europe and the United States at that time, including the origins of Western states - Ancient Greece and Rome.

2 As stated hereinafter, the 'acceptance' of European international law by non-European countries did not amount to blind imitation.

3 Until the middle of the nineteenth century, many international law textbooks with widespread impact were still titled "European international law." See, e.g., G. F. von Martens, Einleitung in Das Positive Europärsche VölKerrecht auf Verträge und Herkommen Gegründet (Göttingen: Den Johann Christian Dieterich, 1796); A. W. Heffter, Das Europäische Völkerrecht der Gegenwart (Berlin: E.H. Schroeder, 1844); J. L. Klüber, Droit des Gens Moderne De L'EuRope, (Paris: Guillaumin, 1861: Nouv. éd., rev.).

4 M. Koskenniemi, Histories of International Law: Dealing with Eurocentrism, 19 ReChtSGeschichte 154 (2011).

5 Many scholars in the last few decades pointed out this from different perspectives. See P. A. CoHEn, Discovering History in China: American Historical Writing on the Recent Chinese Past (1984); Sato Shinichi, Modern China's InTELlectuALS AND Civilisation 近代中国の知識人と文明 (Tokyo: University of Tokyo Press, 1996); Rune SvarverUd, International Law as World Order in Late Imperial China: Translation, Reception and Discourse, 1847-911 (2007); Xue Zhong Ling, From Law of Nations to Diplomacy through International Law 从万国公法到公法外交 (Shanghai: Shanghai Classics Press, 2009); Junnan Lai, International LaW AND tHe Late QING Dynasty 国际法与晚清 中国 (Shanghai: Shanghai People Press, 2015), etc. 
hoped that resistance against Western imperial oppression and cultural invasion, through traces of traditional Chinese culture, would help affirm, publicize, or resurrect Chinese traditional culture. ${ }^{6}$

This research aims to examine views of Chinese intellectuals' of international law in the early twentieth century, focusing on their writings on ancient China's international law. There are four concrete academic reasons of writing this paper. First, in the early twentieth century, there were considerable number of literatures demonstrating that international law had already existed during Spring and Autumn and the Warring States Periods (770 BC 221 BC) in China; these argue that ancient China's international law system, despite certain differences, had structure, principles and specific rules similar to the early twentieth century's European international law. Revealing their historical implication is important to understand contemporary international law.

Second, it is well known that European international law entered into China during the late Qing Dynasty, ${ }^{7}$ but little research has been done with respect to the intellectuals' view of international law in the early twentieth century, especially their view on ancient China's international law. This article has tried to bridge that gap and inspire colleagues' interest with an eye to promote comprehensive and deeper research.

Third, in today's multi-cultural world, reconsidering the Chinese intellectuals' responses and the political interaction with Western ideas in the early twentieth century, is expected to contribute to breakthroughs of conventional ideas and a multi-dimensional understanding of the complex realities of the current world. ${ }^{9}$ This

6 Shuming Liang, Eastern and Western Cultures and Their Philosophies 东西文化及其哲学(Shanghai: Commercial Press, 1922); Ch'IEn Mu, A History of Chinese Thought and Scholarship over the Past 300 Years 中国近三百年学术 史 (Shanghai: Commercial Press, 1937).

7 The representative literature consists of the following: Jiang Tingfu, The Beginning of the Importation of International Law into China 国际公法输入中国之起始, 1 Pol. SCI. Rev.政治研究 61-4 (1932); I. HsÜ, ChInA's ENTERANCE INTO the Family of Nations: The Diplomatic Phase 1858-80 (1960); Tieya Wang, International Law in China: Historical and Contemporary Perspectives, 221 Recuell Des Cours 226-62 (1990); SATo, supra note 5; Eric Yong Joong Lee, Early Development of Modern International Law in East Asia: With Special Reference to China, Japan and Korea, 4 J. Hist. Int’L L. 42 (2002); Tian TaO, The Introduction of International Law and the End of the Qing Dynasty 国 际法输入与晚清中国 (Jinan: Jinan Press, 2001); L. Liu, The Clash of EMPIRES: The InVENTION of China IN Modern World MAKING (2004); SVARVERUd, supra note 5; LING, supra note 5.

8 As far as the author is aware, the only published article on this topic is by Qinhua HE, On the Theory and Practice of Transplanting International Law into China in the Republic of China 略论民国时期中国移植国际法的理论与实践 , 4 L. \& Bus. STUD. 法商研究 136-44 (2001). This article introduced the publications on international law in the period of the Republic of China, and laid the emphasis on the state practice at that time rather than international law thoughts, without touching upon the viewpoints and teachings of the intellectuals of that period on ancient China's international law.

9 With respect to analyses of European and non-European states' mutual interaction against the background of 
will also refute the "single-track development" thinking based on Eurocentrism.

Last but not least, Chinese intellectuals in the early twentieth century committed themselves to exploring and carrying forward ancient Chinese international law not only out of an interest in academic research, but also as a reliable way to establish a condition for an equal dialogue between China and the West. Hence, through the research on ancient China's international law by the then intellectuals, we are able to better understand China's own ideas on how to construct a truly universal discourse system as well as Chinese contemporary conceptions of peaceful co-existence under international law.

This paper is composed of six parts including a short Introduction and Conclusion. Part two will examine translation of W.A.P. Martin and its significance for introducing modern international law into China as well as advocating for ancient Chinese international law. Parts three to five will analyse relevant propositions by Chinese intellectuals in the early twentieth century, chronologically.

\section{The Translation and Introductory Work of W.A.P. Martin}

W.A.P. Martin, an American missionary was the first man to systematically show the relations between ancient China and international law. During his stay in China, Martin translated modern international law writings into Chinese in Beijing Tongwen Guan 同文馆. He also introduced ancient Chinese international law to Westerners. Both tasks had a deep impact on Chinese intellectuals' recognition and understanding of modern international law.

In the beginning, Martin had difficulties in translating English terminologies of modern international law treatises into corresponding Chinese expressions because there were no such concepts in Chinese. For mutual understanding, Martin had no choice but to creatively construct a new, universal legal system applicable to both China and the West. The translation of 'gongfa' (Public Law 公法), e.g., was a delicate one. On the one hand, Martin made full use of the diverse implications of 'gong' 公 in Chinese culture. On the other hand, he, intentionally ignoring the difference meanings between 'international law' and "law of nations" at the time, translated the two definitions uniformly as Wanguo Gongfa (Public Law of All Nations 万国公法)

colonialism, see A. Anghie, Finding the Peripheries: Sovereignty and Colonialism in Nineteenth-Century International Law, 40 Harv. InT'L L. J. 1-80 (1999). 
or simply Gongfa 公法, so as to strengthen its natural law character. ${ }^{10}$ Through such highly subjective translation, Martin encouraged Chinese people to understand the ideal international order under Gongfa with a universal significance.

Besides the translation work, Martin also introduced China to the West. At the International Congress of Orientals in Berlin in 1881, he presented a thesis, Les vestiges d'un droit international dans 1'ancienne Chine which proved that 'international law' already existed in the Spring and Autumn and the Warring States Periods of China. ${ }^{11}$ In his opinion, international law had two prerequisites: the presence of multiple equal States and the necessity for interaction among them. Those two prerequisites were both satisfied at the time. ${ }^{12}$ By analysing literature and records of the time, such as Rites of the Zhou 周礼, Three Commentaries on the Spring and Autumn Annals 春秋三传, and Stratagems of the Warring States 战国策, Martin concluded that in the form of 'rites,' the interacting rules among states in the Spring and Autumn and the Warring States Periods were equivalent to those of modern international law in Europe. He proved that international law had existed in China since ancient times and Chinese people should have a long tradition of abiding by it. ${ }^{13}$

Martin had two clear purposes. First, he was a missionary who was obliged to disseminate Christianity in China which could only be accomplished by reframing Chinese traditional ideas. Second, many Europeans at the time, were reluctant to apply international law outside Europe. ${ }^{14}$ Highlighting the European civilisation as being superior, European international law scholars denigrated non-European

10 These two words, though sometimes misused, represented two different tendencies. Following the tradition of jus gentium, the expression of "law of nations" suggested a meaning of universality and justice, with an emphasis on the natural law. The expression of 'international law,' however, focused on a positive law perspective, emphasizing the will of sovereignty and importance of state practice. Though Wheaton distinguished between "international law" and "law of nations" and clearly expressed his preference for the former in his book, Martin ignored this distinction. See Yongxin Zhang, Some Problems in the Wanguo gongfa 万国公法的几个问题, 42 J. PeKING U. (PHIL. \& Soc SCI.) 北京大学学 报(哲学社会科学版) 83 (2005).

11 After the conference, his speech was first published in French under the title of Les vestiges d'un droit international dans 1 'ancienne Chine, 14 Revue de Droit International et de Lègislation Comparée 227-42 (1882). Afterward, it was reprinted in the English press and included in his English symposium, see Traces of International Law in Ancient China, 14 Int'l Rev. 63-77 (1883); Id., in 14 The Chinese Recorder 380-93 (1883); Id., in Hanlin Papers, or Essays on the History, Philosophy, And Religion Of The Chinese, 2nd Ser. (Kelly \& Walsh eds. 1894), 111-41. Later, this article was also translated into Chinese by his assistant Wang Fengzao under the title of International Law in Ancient China 中国古世公法论略, published by Beijing Tongwen Guan in 1884, and later included in the ANTHOLOGY FOR THE EMPIRE 皇朝蓄艾文编, 19-42 (Yu Baoxuan ed., 1903).

12 Yu Baoxuan, id. at 19.

13 Id. at 25.

14 E.g., at the Institut de droit international session de la Haye in 1875, one such topic was the 'Applicabilité du droit des gens européen aux nations orientales'; whether international law, formed among the 'civilised nations' of Europe, should and could broaden the scope of application to East Asia was fiercely debated by scholars at the conference. See Annuaire De L'institut De Droit International, Cinquiéme Année 132-49 (1882). 
regions as 'semi-civilised' or 'uncivilised'. ${ }^{15}$ They further heralded international law as a product of European civilisation and was therefore, by its very nature, either completely inapplicable outside Europe or only partially/unequally applicable. ${ }^{16}$ Against this backdrop, however, Martin tried to prove that, given the elements of international law in the Spring and Autumn and the Warring States Periods, China was fully entitled to be a member of the Family of Nations.

Martin's commitment to disseminating ancient Chinese international law was consistent with his translation work. In order to expand the applicable scope of modern international law, he had to discover and create a common ideological basis applicable for all States, beyond the cultural bias between the East or the West. Nearly twenty years after the Berlin speech, his opinion regarding international law in ancient China was paid closer attention to by Chinese intellectuals.

\section{The Embryonic Stage}

In the late nineteenth century, China, facing the Western powers' gunboat policy, suddenly found herself as an ordinary, even inferior, member of the global community. This unexpected change had a strong impact on the Chinese people's perception of the contemporary international order. The coexistence of numerous states also reminded Chinese intellectuals of the Spring and Autumn and the Warring States Periods. They pointed out the extreme similarities between ancient Chinese and modern European community. ${ }^{17}$ This comparative thinking sought to encourage the fight against Western imperialism, struggle for survival, and to find a way to overcome the imminent crisis. Because of the urgent desire to save China from extinction, however, these analogical arguments focused just on general and abstract comparison more than further research and microscopic investigation into

15 J. Lorimer, La doctrine de la reconnaissance, fondement du droit international, 16 ReVUe De DroIt InTERNATIONAL ET De Legislation Comparee 335-6 (1884).

16 J. Lorimer, I The Institutes of the Law of Nations: A Treatise of the Jural Relations of Separate Political COMMUNITIES 101-2 \& 216-9 (1883).

17 E.g., Feng Guifen, a famous advocate of the Westernisation movement, wrote: "The overseas 'Yi' groups are similar to the states of the Spring and Autumn and the Warring States Periods, not only in the specific structure but also in the general social atmosphere.” See II Feng Guifen, Jiaobinlu Protestation 校邠庐抗议 214 (Zhengzhou: Zhongzhou Classics Press, 1998, 1st ed. 1861). Also, Tao Wang, a great thinker in the late nineteenth century described: "The four continents in the world are likely to merge from separation, exactly like the situation in the Spring and Autumn and the Warring States Periods". TAo Wang, IV Supplement For the Anthology of TAOYUAN 㢷园文录外编 115 (Beijing: Zhonghua Book Company, 1959, 1st ed. 1882). 
specific rules, mechanisms, and ideas.

It began to change in the early twentieth century when some Chinese students abroad analysed Chinese and Western literature. With the establishment of the Republic of China in 1912, Chinese scholars were able to conduct research on international law better than before; some tried to systematically compare rules and ideas of ancient China to those of modern international law. Numerous research products had been achieved before World War II, which can be divided into three periods at this article, namely 'embryonic stage,' 'developing stage,' and 'maturation stage.' The first period - embryonic stage - refers to the first ten years of the twentieth century, during which some Chinese students expressed their views on this issue in their graduate theses.

A notable example is China's Position in International Law ${ }^{18}$ a master's thesis, written and submitted by Chüan Chang YÜ, a Chinese student at Yale Law School to the graduation committee of Yale University in 1903. This thesis was the first English academic paper in its field written by a Chinese national. Based on the ideas forwarded by Martin in 1881, he compared some Chinese classics with the works of Hugo Grotius, and concluded that a large number of international law regulations had already existed in the Zhou Dynasty (1046 BC 256 BC) such as sovereign equality, power balance, territory, jurisdiction, diplomatic agents system, the law of war and neutrality, etc. ${ }^{19}$ Although substantial sections of this thesis were dedicated to examining international law in ancient China, the author finally advised China to reform her legal system and completely accept the standards and discourse of the West in order to join the contemporary international system as a full member. ${ }^{20}$

Another example is Derun MA (known by his German name as MA Do Yün), Chinese scholar who was awarded a doctorate in Germany. In his thesis submitted to Berlin University in $1907,{ }^{21}$ MA also pointed out that many independent states were already existing in China's Spring and Autumn and Warring States Periods. “The Great Unification” of the Qin Dynasty in 221 BC, however, led China take over the central most position in Asia. ${ }^{22}$

18 Yü Chüan Chang, China's Position in International Law, LL.M. Thesis, Yale Law School, 1903 (on file with Yale Library System).

19 Id. at 3-69.

20 Id. at 73-96.

21 Do Yün Ma, Der Eintritt des Chinesischen Reiches in den Völkerrechtlichen Verband, Dissertation von königlichen Friedrich-Wilhelms Universität zu Berlin (1907). Later, this thesis was translated into Chinese by the author himself. See Do Yün MA, The Correspondence of China's Practice with International Law (Shanghai: Commercial Press, 1908).

22 Id. at 29-34. It is worth noting that the thesis also focused on China's then-contemporary international status. He 
Chüan Chang YÜ and Derun MA maintained similar positions in at least two respects. First, they thought that international law basically existed in ancient China in theory and practice, but the unification of the Qin Dynasty hindered its further development. In this view, China would be able to re-enter the international legal community. Second, they have used the 'civilised' language taught by their Western teachers, quoted Western literature skilfully, and without hesitation adopted Western standards to assess China. Western perception, in their sub-consciousness, might be a universally applicable knowledge. Those two points were exactly what Martin strongly called for and desired. As he wrote in his 1901 memoir, The Lore of Cathay,

Chinese statesmen have pointed out the analogy of their own country at that epoch with the political divisions of modern Europe. In their own records, they find usages, words, and ideas, corresponding to the terms of our modern international law; and they are by that fact the more disposed to accept the international code of Christendom, which, it is no Utopian vision to believe, will one day become a bond of peace and justice between all the nations of the earth. ${ }^{23}$

In the early twentieth century, Chinese students studying in Europe and America responded to Martin's prognosis, though their arguments and demonstrations were slightly coarse. They were only at the embryonic stage. Later in the period of the Republic of China, Martin's assertion achieved a more far-reaching influence.

\section{The Developing Stage}

The developing stage refers to the period between 1910 and 1929, where international law in China was gradually maturing. Some international law scholars published monographs, articles or a specific chapter of textbook relating to ancient Chinese international law.

These scholars, in some ways, followed the perceptions by Martin and early Chinese scholars who had studied outside of China. Many spoke highly of the

confirmed the validity of these treaties, and considered that what China had done in the treaty relationship conformed to the principles of international law. Hence, he concluded that China had already been a full member of the "international law community" and a complete subject of international law. See also id. at 35-75.

23 W. Martin, The Lore of Cathay, or the Intellect of China, 449 (New York: Fleming H. Revell Co., 1901). 
translation and introductory works by Martin in their arguments. ${ }^{24}$ Some of them even quote Martin's article Zhongguo Gushi Gongfa Lunlue in its entirety, ${ }^{25}$ which opposed the application of modern international law to China. E.g., the famous historian Bingsong HE, who obtained his master's degree from Princeton University in 1916 stated that:

Since they [referring to some Western scholars] are unfamiliar with the situation of China, they thought that Martin was on a fool's errand. In their opinion, international law is for civilized nations. How could a country like China possibly be taught how to conform to international law? [...] My intent in writing this article in English, therefore, is to find traces of international law in ancient China and refute the view of those Westerners who decline to admit the existence of international law in China. They did it only because they had never dug into ancient Chinese writings. ${ }^{26}$

New changes and developments emerged during this stage. Since many scholars were mastering both Western and Chinese cultures, they tended to compare international law traditions on both sides more meticulously.

\section{A. Two Rules of International Law}

Throughout the readings of Greek and Roman international law, HE claimed that classical international law of Greek and Roman times would be similar in content to that in Master Zuo's Spring and Autumn Annals 左传. ${ }^{27}$ In his opinion, 'rites' in the Annals could be the same as 'customs' in modern international law. ${ }^{28}$ To prove his point, HE then further cited a large number of historical facts, including diplomatic

24 Huang Jie, Preface, in Biography of the International Law in the Spring and Autumn Period 春秋公法内传 1 (Liu Renxi, 1st ed. 1909, reprinted in 1913). See also Guangce Lan, Author's Preface, in The Origin And Development of International Law in the Spring and Autumn Period 春秋公法比义发微 2 (Nanking: Nanyang Publishing Office, 1911); Bingsong He, Ancient Chinese International Law 中国古代国际法, 2 J. L. \& PoL. 法政学报 (1920). Later, it was included in II Collection of Works By He Bingsong 何炳松文集 6 (Beijing: Commercial Press, 1996); and then XieWAn Ning, I Modern International LaW 现行国际法 34-5. (Shanghai: Commercial Press, 1926).

25 Zhuohong Tan, The Principles of International Law 国际公法原论 15-27 (Shanghai: Zhonghua Book Company, 3rd ed. 1934, 1st ed. 1922).

26 He, supra note 24, at 6. See also Xincheng Zhang, Author's Preface, in International Law in the Spring And Autumn PerIod 春秋国际公法 7-8 (Beijing: Yonghua Publishing House, 1924). Moreover, both writers of the preface of Zhang's book - Yan Huiqing, a Senior Official in the Nanking National Government, and V. K. Wellington Koo, a very famous diplomat also strongly supported this argument. See Huiqing Yan \& V. K. Wellington Koo, Preface, in International Law in the Spring and Autumn Period 春秋国际公法 1-6 (Beijing: Yonghua Publishing House, 1924).

27 He, supra note 24 , at 6.

28 Id. He said: "International customs are the source of modern Western international law, while the rites among states are the origin of ancient China's international law." 
delegations, treaties, alliances, international interventions, etc. ${ }^{29}$ Zhuohong TAN also argued:

In the Spring and Autumn and the Warring States Periods, feudal lords governed their own states separately, while all of them were loyal to the Emperor of Zhou; similarly, in medieval Europe, all European states were self-governed, while they were under the command of the Pope. Therefore, an international community had already formed in ancient China. ${ }^{30}$

Xiewan NING listed state practices during the ancient time, such as visits and alliances, peaceful negotiations, disaster aid among states, trade, and concluding treaties. Based on this observation, he stated that, if there had been scholars in ancient China who, like Hugo Grotius, categorised different types of general practices of international law of that time and wrote them down, "Eastern international law might well have been the cradle of global civilisation."

Chinese international lawyers not only recognized ancient China's rules and practices of international law similar to the West, but also considered those practices and rules as a part of an ancient civilisation. Though these rules and practices were not completely handed down to the present, they demonstrate the feature of ancient Chinese civilisation.

Furthermore, some scholars considered the specific situations of ancient China and pointed out their differences from modern international law. Xincheng ZHANG argued that:

The background of the Spring and Autumn Period is quite different from the current situation. Therefore, it is not wise to observe history from a purely modern perspective. In a nutshell, ancient international law was tailored to the needs of that age and could not be identical to modern international law. ${ }^{32}$

As diplomatic delegates in the Spring and Autumn Period had no counterparts in modern international law, ZHANG himself created and interpreted new names such as “non-permanent plenipotentiary” 会盟专使, 'temporary plenipotentiary' 聘使, “special agents to attend the funerals of other feudal lords or nobles” 会 
葬使、串使, etc. ${ }^{33}$ Unlike early Chinese students outside of China, who took Western standards for granted to measure China's situation and believed that Chinese materials could only be used to prove the validity of Western theories, ZHANG intended to treat modern international law only as a reference. He thus deliberately moved from passively absorbing the knowledge of international law from the West to consciously developing indigenous research. Even if so-called 'indigenous research'could only be defined with reference to the West, it indicated that international lawyers, instead of only adhering to the Western standards, had gained some measure of independence in international law research. ZHANG's work, however, just uncovered some local rules prevalent in ancient China. He did not consider whether these ancient practices could be used to enrich and improve contemporary international law or even contribute to the transformation of current international order. He treated them as historical relics; no more than a set of local customs applied in a specific region.

\section{B. Two Histories of International Law}

Some scholars compared the histories of international law of China and the West. They claimed that China would have a longer history than the West in international law. ZHANG Xincheng said that "The idea of international law is found earliest in East Asia and was most developed during the Spring and Autumn Period, which preceded the creation of jus gentium in Rome."34 Xiewan NING, a prominent jurist, further pointed out that independence and equality of states were two prerequisites for the birth of international law. The practices of the Spring and Autumn Period had fulfilled these requirements, while the ancient Greeks, who treated foreigners as barbarians and captives as slaves; and the ancient Romans, who aimed to conquer the whole world and build the only one empire, did not tolerate the existence of other independent and equal states. Their practices were contradictory to the fundamental principles of international law and could not possibly have given birth to modern international law. ${ }^{35}$ Therefore, he argued "international relationships and the ideas of international law originated earlier in the East than in the West."

This analysis does make a point. Modern international law arose in the midseventeenth century. It was born much later than Chinese international law, existing

\footnotetext{
Id. at 227-33.

34 Id. at 2.

35 Ning, supra note 24, at 34.

36 Id. at 35.
} 
during the Spring and Autumn and Warring State period (770 BC 221 BC). Yet, this is just mere historical significance, since it was not succeeded to the Qin Dynasty, the first unified empire of China. ZHANG further argued that Chinese international law in the Spring and Autumn Period was more thoughtful and idealist than modern international law. In ancient China, the primary criteria to be a member of the international society were related only to the level of civilisation, rather than races or religions. Therefore, compared to the views expressed by some Western scholars that international law was applicable only to Christian nations, Chinese international law in the Spring and Autumn Period was closer to achieving the goal of a utopian social order. ${ }^{37}$

Modern international law is based originally on Christianity and the European identity. At the dawn of the colonial age, this legal system was expanding to vast areas outside of Europe. As Schwarzenberger has suggested, "[T]he price which the European law of nations had to pay for universality was increasing separation from its Christian foundation and dilution of its ethical contents." 38 Accordingly, a more comprehensive and flexible concept of 'civilisation' emerged with a new value. Whether there existed clear criteria for the identification of 'civilisation' during the late nineteenth and early twentieth centuries is debated by publicists, ${ }^{39}$ but the existence of a discourse on civilisation was always recognised. Therefore, Zhang's opinion that international law increasingly took race or religion as its threshold is not entirely accurate.

An alternative perspective, however, may elucidate the concept of civilisation during this period more accurately. It means the concept of 'civilisation' was often used as a tool for oppression and exclusion, rather than unification and integration. Even if the subject of international law had shifted from the Christian and Caucasian nations to all 'civilised nations,' as long as such 'civilisation' only stood for European civilisation, and the West was not willing to conduct equal communication with heterogeneous civilisations, such criteria would continue to reinforce discriminatory policy ingrained in Eurocentrism. ${ }^{40}$ In fact, the application of such criteria justified

37 Zhang, supra note 26, at 6-7.

38 G. Schwarzenberger, The Standard of Civilization in International Law, 8 Current Legal ProB. 220 (1955).

39 Gong asserted that a clear standard of civilization existed in international law in the nineteenth century, and enumerated some critical elements of it. See G. Gong, The Standard of 'Civilization' In International Society 14-5 (1984). His arguments, however, were questioned by other scholars. See M. Koskenniemi, The Gentle Civilizer of Nations: The Rise and Fall of International Law 1870-1960, 132-6 (2001); B. Buzan, The "Standard of Civilization" as an English School Concept, 42 Millennium: J. InT’L Stud. 580 (2014). In this regard, see also LaI, supra note 5, at 6-7.

40 Schwarzenberger points out that this 'civilized' standard is but a relationship of power and politics which acquires legitimacy under the guise of international law theories. See G. Schwarzenberger, The Inductive Approach to InTERNATIONAL LAW 60-1 (1965). Taking this as proof, Anand criticizes the imperialist and colonialist elements in the 
a massive Western colonisation campaign against non-Western nations. Dichotomy over civilisation allowed modern international law to devolve into a Eurocentric system, thereby justifying discrimination against non-European civilisations. ${ }^{41}$

What Chinese scholars experienced in the early twentieth century were certainly the oppressive and exclusive aspects of modern international law. In this sense, ZHANG's critique of Eurocentric international law had a unique significance. In his mind, while modern international law functioned as the rhetoric for justifying colonialism, ancient Chinese international law was open to alien nations both in theory and practice. It was clear that the latter was "closer to achieving the goal of a utopian social order."

Besides Xincheng ZHANG, some other scholars in that period, such as Guangce LAN, Zengxiang FAN, and Bingsong HE compared Confucian tradition with Christian or Greek and Roman cultures. ${ }^{43}$ They did not, however, systematically and comprehensively analyse ancient Chinese international law as Xincheng ZHANG did. Nevertheless, they brought attention of the academia to ancient Chinese international law and laid a solid foundation for further study.

\section{The Maturation Stage}

The maturation stage refers to the approximate ten-year's period between 1930 and the eve of the Second World War. Almost one hundred years had passed since the intellectuals of the late Qing Dynasty first became exposed in a substantive way to Western thought. ${ }^{44}$ The scholarly accumulation in China peaked in this period with higher research levels in Chinese international law than that in post Second World War.

Although most intellectuals followed earlier approaches, their intensive research was still motivated by some Western scholars' criticism of China. In order to defend China in a more persuasive way, they continued to refer to Martin's thesis ${ }^{45}$ as well

international legal order. See R. Anand, Role of the "New" Asian-African Countries in the Present International Legal Order, 56 AM. J. INT'L L. 386-9 (1962).

41 C. Alexandrowicz, The European-African Confrontation, A Study in Treaty Making 6 (1973).

42 Zhang, supra note 26, at 7.

43 For instance, Lan, supra note 24, at 5-6; Id. at 1, Zengxiang Fan, Letter from FAN Zengxiang; HE, supra note 24, at 11.

44 Vattel's writings were first translated into Chinese before the First Opium War in 1939, from which point Chinese intellectuals were in contact with the Western learning.

45 Daren Liu \& Guogin Yuan, The History of Development of International Law 国际法发达史 19 (Beijing: China 
as other favourable opinions of Chinese and foreign scholars. ${ }^{46}$ This reference was to not only provide proof, but also point to the problem in prior research. ${ }^{47}$ They finally achieved the goal of "proving in a scientific way whether there had existed the basic principles of international law in ancient China." 48 These critical analyses contributed to a solid tradition of academic thinking and pushed research in this field to a relatively mature stage. Chinese scholars in this period seldom conducted a simple China $v$. West comparison of legal rules; they focused more on a positive approach with system building and legal sources embedded in ancient Chinese international law. Their endeavours transcended just academic enthusiasm. It will be examined from the perspectives of the system building and the legal sources theory.

\section{A. System Building}

First, intellectuals at this stage were no longer satisfied with individual approaches only to a few specific issues. Instead, they were dedicated to establishing a comprehensive and systematic research method. Traditional topics such as diplomatic delegations, the conclusion of treaties, alliances, and war were analysed in an integrated cognitive manner.

A notable academic attainment is The Relics of International LaW In the Pre-Qin PERIOD 先秦国际法之遗迹, ${ }^{49}$ written in 1931 by Dr. Tchoan-Pao SIU who was awarded a doctorate in law by the University of Paris. He also authored the thesis titled Le droit des gens et la Chine antique. Dr. SIU originally planned for it to comprise two volumes: the first volume was Les idées, discussing famous teachings of philosophers on international relations and the second volume was Les faits, examining cases of interactions between states, both prior to the Qin Dynasty. Due to constraints of time, he only managed to publish the first volume ${ }^{50}$ in Paris. After returning to China, SIU spent another six years reassembling and reorganising materials and finished the second volume titled The Relics of International LaW in the Pre-Qin

Fangzheng Press, 2006). It was collated by Juan Hu with the 1937 version of the Shanghai Commercial Press. See Junpei Hong, International Law in the Spring And Autumn Period 春秋国际公法 4-8 (Shanghai: Zhonghua Book Company, 1939).

46 E.g., Hong Junpei quoted the works of French scholar Louis Le Fur, Belgian scholar P. Ven Hée, English scholar Geles, and Chen Guyuan, Siu Tchoan-Pao, and Ning Xiewan. See Hong, id. at 4-10.

47 See the critical analysis by Hong Junpei to W. Martin and Louis Le Fur, see id. at 6-7 \& 8-9, respectively.

48 Id. at 14. [Emphasis added]

49 Tchoan-Pao Siu, The Relics of International Law in the Pre-Qin Period II 69-70 (Shanghai: China Science Company, 1931).

50 Tchoan-Pao Siu , Le Droit Des Gens Et La Chine Antique, Partie I: Les Idees (Paris: Librairie De Jurisprudence Ancienne Et Moderne, 1926). 
PERIOD.

The structure of this thesis is significantly different from the prevalent textbooks of general international law at the time. The thesis consisted of two parts: (1) diplomatic institutions and (2) international relations. The latter was further divided into three major domains, public international law, international criminal law, ${ }^{51}$ and private international law. In particular, the public international law part occupies more than half of the whole book; it is divided into another four categories: 'harmonious relationship'和谐关系, 'unfriendly relationship' 不睦关系, 'warring relationship' 战争关系, and 'alliance relationship' 会同关系. As the standard to distinguish these four categories of international relations, he indicated that the three former categories were pertinent to the relationship between two or several states, while the last one was established by multiple states. ${ }^{52}$ The former three constituted a progressive structure, representing the three phases of international relations: (1) peaceful co-existence to occurrence, (2) settlement of disputes, and (3) the breakout of war. This was essentially identical to, albeit more detailed than, prevalent Western international law textbooks at that time, which only divided international law into 'peacetime' and 'wartime. ${ }^{53}$ This three-phase division not only took into account the characteristics of ancient Chinese international law, but also manifested the writer's unique comprehension of the contemporary international relations.

In this book, Dr. SIU made further detailed elaborations and created a complex systematic construction. E.g., he analysed 'harmonious relationship' from four those perspectives as 'political relationships' 政治关系, 'economic relationships' 经济关 系, 'legal relationships' 法律关系, and 'compassionate relationships' 恻隐关系. ${ }^{54}$ The political relationship part further established a "formal political relationship" and a "substantive political relationship." The former included "exchange of envoys between states" 聘问 (embraced "which at the time of a new monarch enthronement" 值新 君接位之聘问 and “which in normal times” 平时聘问, the former of which has three further sub- layers), "receiving and welcoming in the border regions" 郊劳, and

51 Under the category "international criminal law," the author dealt with some state practices concerning extradition and asylum. Supra note 49, at 305-14.

52 Id. at 303.

53 R. Phillimore, I-III Commentaries upon International Law (London: Butterworths, 3d ed. 1879-85). See also T. Lawrence, The Principles of International Law (London; Macmillan, 1895); H. Hall, A Treatise on International Law (Oxford: Clarendon Press, 4th ed. 1895); J. Westlake, International Law, Part I: Peace (Cambridge: Cambridge University Press, 1904); J. Westlake, International Law, Part II: War (Cambridge: Cambridge University Press, 1907).

54 Supra note 49 , at 11-68.

55 Id. 
“foreign monarch reviewing troops at home" 偕蒐.

Dr. SIU suggested that the 'alliance relationship' before the Eastern Zhou Dynasty was temporary, succeeded by, in effect, an international organisation. A most typical one is the Tongmeng Hui 同盟会 established by Duke Huan of Qi ${ }^{57} \mathrm{He}$ opined that upon the emergence of international disputes or in wartime, different types of the 'alliance relationship' always existed. These historical instances were meticulously sorted and examined according to their categories, establishment, organisation and institutional design with details including the frequency, venue, topic, procedure and rites of assembly. ${ }^{58}$

This newly created methodology was based on his comprehensive examination of international law practice in ancient China. He used terms in accordance with the nature of the subjects examined in ancient classics rather than unthinkingly adopting those used in modern international law.

Such approach was not rare in the writings of this period. A masterpiece is Tracing THE SOURCES OF Chinese International LAW 中国国际法溯源 ${ }^{59}$ written by Guyuan CHEN, a famous jurist in the Republic of China in 1933. This book consisted of four parts. The first part was equivalent to a pandect, covering general issues including subjects and objects of international law, international activities and diplomatic delegations, international justice and international disputes settlement, etc. The other three parts were dedicated respectively to "diplomatic relations in normal times” 常时之邦交, ‘temporary strategies”临时之策略, and “rules in wartime” 战时之法则. “Diplomatic relations in normal times” examined the rules including 'pilgrimage' 朝觐 as well as “exchange of envoys between states” 聘问 and “consolation and condolence” 节恤; ‘temporary strategies' discussed institutions such as 'alliance' 会同, “concluding covenants, taking oaths, and otherwise rites among lords and nobilities to consolidate internal unity and strike enemies” 盟誓， "obtaining other states" confidence by sending relatives or important ministers as hostages”质执, and the like. ${ }^{60}$ Although CHEN's classification method differed from that of SIU, in overall structure, he, as SIU did, by and large followed prevalent Western dichotomy dividing international law into 'peacetime' and 'wartime,' in a more detailed and more Chinese way. Later, Daren LIU and Guoqin YUAN, who wrote The History of Development of InternAtional LAW almost completely

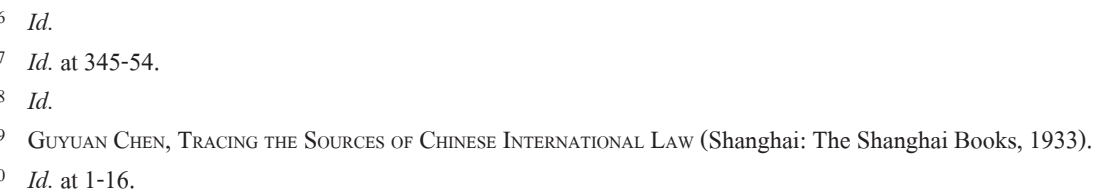


internalised CHEN's views. ${ }^{61}$ Also, Junpei HONG, who studied in Belgium and France, not only referenced CHEN's viewpoints, ${ }^{62}$ but also invited CHEN to write a preface for his work titled, InTERNATIONAL LAW IN THE SPRING AND AUTUMN PERIOD 春秋 国际公法. ${ }^{63}$ These works demonstrated that CHEN's idea was highly recognised by the contemporary fellow scholars.

These self-created systems had reached a relatively high level of systemisation, revealing Chinese scholars' original thinking and their distinctive perception of international law. In spite of drawing some knowledge from modern international law, the new rules were extracted entirely from the induction and refinement of ancient Chinese international law and practices. Such a conclusion precisely contrasted the view of the then Western positive international law, as analysed in this paper so far. The works of SIU and CHEN proved the abundant practices of ancient China; they showed ancient Chinese international law had rich content and systemic completeness no less than modern international law. In this sense, modern international law could be evaluated just as 'local knowledge' of Europe, rather than universal truth. Today's global expansion of so-called "European international law" cannot be thus regarded as the universalisation of international law. True universalism does not stem from unilateral expansion; it must derive from genuine intellectual interaction.

\section{B. Legal Sources}

Apart from structural innovations, scholars of this stage also made many interesting observations on the sources of ancient Chinese international law. Guyuan CHEN, e.g., held 'supreme decree' 最高法令 (the ritual system enacted by the Emperor of Zhou dynasty), 'international usage' 国际惯例, and 'international covenant' 国际盟 约 as primary sources of international law, while 'natural law'自然法则 and 'classics' 典籍 were secondary sources in the Spring and Autumn Period. ${ }^{64}$ Similarly, Junpei HONG argued that international law in ancient China was constituted by natural law, traditional system of the Zhou Dynasty, customs, treaties, and domestic law. ${ }^{65}$ In other words, they all tried to combine the two kinds of sources - natural and positive law. Some western international law scholars of the late nineteenth or early

\footnotetext{
61 Liu \& Yuan, supra note 45, at 18-30.

62 Hong, supra note 45, at 10-1.

63 Supra note 60 , at $1-3$.

64 Id. at 4-6.

65 Hong, supra note 45, at 58-64.
} 
twentieth century (generally legal positivists) accepted that customs and treaties were the two primary sources of international law. The then Western literatures of international law did not consider 'natural law' as another source of international law. ${ }^{66}$ Although some Western scholars such as Henry Wheaton did not abandon natural law as a source, when it came to specific rules or regimes of international law, natural law was usually left behind. ${ }^{67}$ On the contrary, Chinese scholars of that era not only adopted this dual-perspective approach, namely, a combination of naturalism and positivism, or a combination of universally applicable legal principles and concrete diplomatic practice, but also simultaneously insisted on a combined perspective in the substantive parts of their works. ${ }^{68}$ This approach was not merely an unconscious mixture or a simple reconciliation of the two methodologies, but rather a deliberate and purposeful approach.

In fact, international lawyers of the classical period such as Hugo Grotius, Samuel von Pufendorf and Emer de Vattel recognized international law as a part of or originating from natural law as a representation of absolute reason or the will of the God. As international law possessed a priori universality, according to the natural law, it could be thus applied to all States equally; irrespective of whether they were Western or non-Western, they could enjoy equal membership of this universal order. ${ }^{69}$ When positivism dominated international law in the nineteenth century, however, it opposed this transcendence. Positivists emphasised that international law was a product of the will of sovereign States, so that its contents should derive from diplomatic practices among them. ${ }^{70}$ The positivist approach revealed at least three political implications. First, international law did not have universal transcendence. On the contrary, its universality was to be realised by concrete historical practices of international law. Before then, international law should not be applied to a strange region. Second, because positivism in international law was not concerned about 'justice' under natural law, but relied on diplomatic practices, no matter how 'unjust' an international treaty or custom followed by States might

66 At that time, some mainstream publicists, such as R. Phillimore, T.E. Holland, W.E. Hall, T.J. Lawrence, and J. Westlake, however, did not adopt this kind of view.

67 H. Wheaton, Elements of International Law (Philadelphia: Carey, Lea \& Blanchard, 1836); later versions adopted the same approach.

68 Except for Chen and Hong, many scholars at that time adopted the "dual-perspective approach." E.g., Zhang Xincheng indicated that the sources of international law in ancient China should include natural law, the traditional system of the Zhou Dynasty, rites, theories and writings, international custom, treaties and resolutions of international conferences, regulations of each state, judgments, diplomatic history and diplomatic documents, etc. See Zhang, supra note 26, at $8-21$.

69 A. Nussbaum, A Concise History of the Law of Nations 114-8 (1950).

70 Id. at $118-25$. 
seem (e.g., consular jurisdiction), it would still be regarded as a "rule of law" due to its general acceptance by States. ${ }^{71}$ Third, the nineteenth century positivism discarded some basic elements of classic naturalism to provide a theory for effectively limiting the members and candidates of the "Family of Nations." Charles H. Alexandrowicz points out:

The replacement of the universal law of nations by positive European international law meant the reduction of non-European State entities which had enjoyed a full legal status within the pre-nineteenth-century family of nations to the position of candidates for admission to its membership or for recognition by the founder members of the European community of states. ${ }^{72}$

In fact, positivism in international law has a strong affinity with the concept of 'civilisation.' Antony Anghie considered that distinguishing between 'civilised' and 'uncivilised' nations is a key characteristic of positivism. In his narrative, positivism in international law is inevitably linked to "the nineteenth century colonial encounter," while 'civilisation' deprives the non-Western world of its equal rights. ${ }^{73}$ Due to the absence or lack of 'civilisation' of non-Western countries, according to him, their sovereignty had to be degraded or weakened in many fields. In comparison with naturalism which brings all nations into the system of international law, positivism and the discourse of 'civilisation' in international law provided ideological justification for a geopolitical confinement: international law only exists between European States and the US that had a 'civilized' and extended diplomatic practice. $^{74}$

For Chinese scholars in the early twentieth century including Guyuan CHEN and Junpei HONG, the "dual-perspective approach" itself precisely represented a resistance against the above-mentioned trend. In their eyes, the universalism of traditional China corresponded to the Western naturalism to a certain extent, ${ }^{75}$ which implies 'inclusiveness' rather than 'exclusiveness.' Also, the diplomatic

71 LAI, supra note 5, at 11.

72 C. Alexandrowicz, An Introduction to the History of the Law of Nations in the East Indies: 16th, 17th, and 18th Centuries 10 (1967).

73 Supra note 9 , at $1-80$.

74 LAI, supra note 5, at 10-3.

75 As shown by the discussion in the works of Chen and Hong, it is of course undeniable that they did not study much about the origin and essence of Western naturalism, but perceived common grounds between Western naturalism and traditional Chinese thinking from the perspective of universalism. As a matter of fact, Western naturalism derived from Christian theology differs in many aspects from traditional Chinese thinking of universalism. 
practices between states in the Spring and Autumn and the Warring States Periods were at least as effective as that of contemporary Western nation State. Founded on the "dual-perspective approach," ancient Chinese international law was not only able to prove China as a 'civilized nation' entitled to equal rights under international law, but was even superior to positivist modern (European) international law that had abandoned naturalism, because of the former's greater inclusiveness and better balance.

This superiority is also reflected in CHEN's work which recounted the ritual system of the Zhou Dynasty as a source of international law. Though there was by no means a basis in existing Western literature to support it, such an idea was not a mere whim, but was rather based on these Chinese scholars' understanding of the relationship between the Emperor of Zhou and the feudal lords, and their integral imagination of international orders. CHEN explained his view as follows:

At first glance it seems unreasonable that ancient Chinese international law was applied according to the supreme decree [namely, the ritual system of the Zhou Dynasty], since the existing international law was based on the principle of equality of nations, which means that no state was superior to others; otherwise it would be domestic law rather than international law. In my humble opinion, however, such international law is not true international law. - I prefer to call it diplomatic law. Only when there is a super-state organization, such as a world republic or a federation of nations, which oversees the application of international law, can international law be truly effective; otherwise it would not be able to have such effect. The Emperor of Zhou was above those feudal lords, but they each were a component of the Zhou Empire, and obeyed the ritual system enacted by the Emperor of Zhou. Moreover, though the Emperor was the supreme authority, he did not infringe upon the lords, except that he would launch an imperial conquest if an infringement or invasion occurred between lords. Under this system, international law functioned well and international peace was maintained. Since Zhou treated lords with the etiquette for guests, it considered itself a member of the international community even though it was at the same time the legislator and the judge. ${ }^{76}$

CHEN opined that: (1) the universal and prevalent authority of the Emperor of Zhou exerted a binding force on the behaviour of feudal lords, and thus contributed to the maintenance of inter-state peace and the strengthening of 'international law';

(2) It could be thus called "true international law" in a form superior to modern 
international law. ${ }^{77}$ In other words, international law adequately functioned only when there existed, above various independent and equal states, a universal order or a superior entity like a 'World Republic' or 'International Federation. ${ }^{78}$ In ancient China, the Emperor of Zhou served as a 'transcendent existence' playing this role. The "international law above states" and the "international law between states" were not incompatible; the former guaranteed effective operation of the latter. To some extent, such a universal order, embedded in the man-made ritual system, was not unlike natural law. Even though the two traditions were substantively different in their origins and contents, they were identical to the proposal of their universal validity to rule over all States.

Based upon this, CHEN further classified ancient Chinese international law into four categories: (1) “international rules” 礼, (2) “international morals" 信, (3) “international comity” 敬, and (4) “international axioms” 义. ${ }^{79}$ He summarized:

\footnotetext{
International rules facilitate the practice of international axioms, international morals promote the observance of international rules, while international comity facilitates the practice of international rules. International rules, international morals, and international comity supplement each other and together help preserve international axioms. This is the comprehensive outlook of international relations in ancient times. ${ }^{80}$
}

Such an interpretation embodied Chinese imagination and narrative in an ideal international law and social order, which included but should be not limited to a group of rules. One might rather stress its underlying values of 'heavenly principles,' 'human relations,' and 'kingly ways,' which were believed to be consistent with the Western natural philosophy or even more reasonable than Western values prevalent in the current international order. This interpretation of the sources of international law was the most incisive summary of ancient China's international law by a Chinese intellectual.

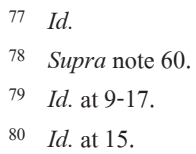




\section{Conclusion}

In this article, we have examined all the basic views on ancient Chinese international law from Chinese scholars of the early twentieth century. Recalling Martin's translations in the late nineteenth century, one will discover that his recognition of the natural law basis and universal order underlying positive international law were, to some extent, continued by works of Chinese scholars. This recognition, however, was contrary to the mainstream view in the West at the time.

Some non-European countries that absolved modern international law were influenced by such trend. After the Meiji Restoration, Japan, e.g., adopted a pragmatic approach in learning and applying international law. Their predominant thinking was that international law should be subordinate to and justified by power politics. Consequently, Japanese scholar Mitsukuri Rinsyo coined the word 'kokusaiho' 国際法 ${ }^{81}$ in his translation of Theodore D. Woolsey's InTRODUCTION TO THE StUdy of International LaW. The word later replaced Martin's 'bankoku koho’ 万国公 法 and became the general translation of 'international law' in East Asia. ${ }^{82}$ In Japan, the concept of 'international law' was no longer the law of reason with universal validity to rule over all States. Instead, it became international rules created by equal States through treaties and customs, backed by the will of sovereigns. At the same time, Japanese international law scholars took the opportunity of the First SinoJapanese War of 1894-1895 to mount a "campaign of international law" against Western readers; they were propagandizing that Japan 'complied with' international law, while China completely disregarded international law. ${ }^{83}$ This campaign contributed significantly to European and American scholars in an effort to promote Japan from a 'barbaric' nation to a 'civilised' one. Japan's understanding of international law and her corresponding actions towards others directly influenced China's political path and destiny; it even had an impact on the Western perception of China's status in international law.

After China was defeated in the Sino-Japanese War of 1894-1895, young Chinese

81 T. Woolsey, Introduction To The Study Of International LaW 国際法、一名万国公法(上編)(Mitsukuri Rinsyo trans. Tokyo: Kobundo, 1875).

82 Hozumi Nobushige, A Night Talk about the Legal Circle 法空夜話 179 (Tokyo: Yuhikaku Press, 1932).

83 Ariga Nagao, La Guerre Sino-Japonaise: Au Point De Vue Du Droit International, ouvrage accompagné d'une préface par Paul Fauchille, (Paris: a. Pedone, 1896). See also Takahashi Sakuyé, The Application of International Law during the Chino-Japanese War, 14 LaW Q. Rev. (1898); TAKahashi Sakuyé, Cases on International LaW During The Chino-Japanese War, with a preface by T.E. Holland, and an introduction by J. Westlake (Cambridge: Cambridge University Press, 1899). 
scholars came to Japan and transplanted Japanese writings of international law into Chinese. Since the early twentieth century, the position of 'wanguo gongfa' in the Chinese vocabulary has gradually been overtaken by 'guojifa' (the latter refers to laws among equal States rather than above them.) As the change in terminology reflects the transition in zeitgeist, it signifies the prevalence of realist thinking in international relations over idealist expectations.

This was a reflection of global realities at the time. The international order of the early twentieth century could be called 'colonisation.' This so-called 'jungle law'supported colonial clashes and raised Western powers to their heights. Ravaged by colonialism, many Chinese intellectuals were profoundly discontented with the illusion of wanguo gongfa introduced by Martin, ${ }^{84}$ while, on the other side, traditional thoughts of universalism were declining.

In the early twentieth century, however, a group of scholars most of whom had studied abroad argued for the existence of 'international law' in ancient China. They were looking for the underlying value of maintaining a universal order, by analysing ancient Chinese State practice. Arguing for the existence of "ancient Chinese international law" might be a reasonable way to protest against Western colonisers armed with weapons and heavy-handed laws - often using the latter to justify the former. When firmly refuting Western scholars who disregarded or even despised Chinese civilisation, these intellectuals stood with Martin. With the time-honoured and brilliant legal culture as well as positive practices, China could be a member of the contemporary international community. By absorbing modern international law into traditional thought of the world order, China could be a truly global country. In this sense, exploring ancient Chinese international law is key to maintaining Chinese people's cultural identity as well as self-esteem in the time of brutal Western imperialism. It is still meaningful to create a truly universal discourse. Chinese people are looking forward to contributing to peaceful co-existence.

Unfortunately, most of their efforts have been nearly forgotten. They might be, however, destined to fight for illuminating Chinese ancient civilization. Todays' readers can truly envision that these faded writings are not only academic assertions, but also the final splendour of an aged empire. It may be the swan song of Chinese intellectuals who rose up against the oppression of imperialist powers and sought a more balanced order in the contemporary world. If their efforts are to be revived, the swan song could be akin to a phoenix rising, initiating renewal of such ideals back into consideration.

84 Guanying Zheng, in I Collection of Works by Zheng Guanying, 389 (Xia Dongyuan ed. Shanghai: Shanghai People Press, 1982, 1st ed. 1882). See also WANG, supra note 17, at 33. 
